\title{
頭頸部癌術後補助免疫療法としての Sizofiran（SPG）の臨床評価
}

\author{
福長 功・白砂兼光・古澤栄之・㴰 智弘 \\ 芝野勝一・大倉正也・吉岡秀郎 \\ 森岡成行・浦出雅裕・松矢篤三
}

\section{Clinical evaluation of adjuvant immunotherapy with Sizofiran (SPG) for postoperative head and neck cancer}

\author{
Isao Fukunaga - Kanemitsu Shirasuna - Hideyuki Furusawa \\ Tomohiro TAKI Y Yoshihito SHIBAno • Masaya OKURA \\ Hideo Yoshioka - Shigeyuki Morioka \\ Masahiro URAde - Tokuzo Matsuya
}

\begin{abstract}
Sixty one patients with oral squamous cell carcinoma received radical tumor excision. Of these, 30 patients were treated with polysaccharide Sizofiran (SPG) for postoperative adjuvant immunotherapy. SPG was intramuscularly given at a dose of $40 \mathrm{mg}$ once every 2 weeks. The 3-year survival rate of the 30 patients treated with SPG was $95.2 \%$. It was significantly higher than $78.4 \%$ of the 31 untreated patients $(\mathrm{P}<0.05)$.

Moreover, the study on immunological parameters, including counts of lymphocytes, OKT3 and OKT4 subsets, and activity of IL-2 produced by the lymphocytes, suggested that SPG promoted the recovery of cellular immunity which was reduced in the patients who had received radio-and/or chemotherapy.
\end{abstract}

Key words: head and neck cancer (頭頸部癌), adjuvant immunotherapy (補助免疫療法), sizofiran (シゾフィラン)

緒

言

頭頸部癌の主たる治療法は, 外科的手術之放射線療法 であるが，それらの治療成績には限界がある。すなわ ち, 上記の手段から逃れた一部の癌細胞が, 後に増殖 し，再発，再然，後転移を生じることもまれでない。そ こでこれら一部の癌細胞の增殖阻止のために, 術後の補 助化学療法や免疫療法を合理的に組合せる必要がある。 特に放射線や根治手術は, 担癌主体にとって免疫能の負 の因子となりらることがよく知られている。

SPG (Sizofiran) は，担子菌スニヒ口タケ (Schizo-

大阪大学透学部口腔外科学第 1 講座

(主任：松矢篤三教授)

The First Department of Oral and Maxillofacial Surgery, Osaka University Faculty of Dentistry (Chief: Prof. Tokuzo Matsuya)

受付日：平成 3 年 4 月 24 日 phyllum commune fries) の菌系体の培養万液から得ら れたグルコースのみからなる多糖体であり，抗腫瑒刹と して広く用いられている，本剤の抗腫瘍効果は，腫湯細 胞に対し直接的に作用するものでなく，宿主介在性に発 揮される、すなわち，動物実験において下細胞，マクロ ファージ相互作用によるキラーT細胞, NK 細胞, LAK 細胞の誘導をSPG が増強することが認められてい る ま) また SPG は各種サイトカイン IL-1, IL-2, IL-3, CSF, INF- $\gamma$ などの産生を増強するとされてい る. 臨床的には子宮頸部癌に対して，放射線療法との併 用効果がすでにあきらかにされている4).

今回, われわれは頭頸部癌患者の一次治療後, 補助療 法の目的で SPG を投与し, その延命効果, および免疫 パラメーターの㛟索分析を行い検討したので報告する.

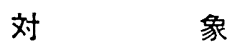

1986年 1 月から1988年12月までの 3 年間に, 大阪大学 
表 $1 \mathbf{a} \quad \mathrm{SPG}$ 投与群の年龉分布

\begin{tabular}{c|l|l|l|l}
\hline 年龄(歲) & 男 & 女 & 計 & $(\%)$ \\
\hline $30 \sim 39$ & 1 & 1 & 2 & $(6.7)$ \\
$40 \sim 49$ & $4(2)$ & 1 & $5(2)$ & $(16.7)$ \\
$50 \sim 59$ & $8(3)$ & 1 & $9(3)$ & $(30.0)$ \\
$60 \sim 69$ & 3 & 3 & 6 & $(20.0)$ \\
$70 \sim 79$ & 2 & $6(3)$ & $8(3)$ & $(26.7)$ \\
\hline 計 & $18(5)$ & $12(3)$ & $30(8)$ & \\
\hline
\end{tabular}

平均年路 58.8 藏
表 $1 \mathbf{b}$ 非投与群の年嚙分布

\begin{tabular}{c|l|l|l|l}
\hline 年龄(龃) & 男 & 女 & 計 & $(\%)$ \\
\hline $30 \sim 39$ & 2 & & 2 & $(6.5)$ \\
$40 \sim 49$ & 2 & $3(1)$ & $5(1)$ & $(16.1)$ \\
$50 \sim 59$ & $6(1)$ & $2(1)$ & $8(2)$ & $(25.8)$ \\
$60 \sim 69$ & $8(2)$ & 4 & $12(2)$ & $(38.7)$ \\
$70 \sim 79$ & 2 & $1(1)$ & $3(1)$ & $(9.7)$ \\
$80 \sim 89$ & & 1 & 1 & $(3.2)$ \\
\hline 計 & $20(3)$ & $11(3)$ & $31(6)$ & \\
\hline
\end{tabular}

平均年龄 58.6 㫌

* $2 \times \mathrm{n}$ のカイ 2 乗テストによって年路は $\chi^{2}=5.32<11.07(\mathrm{P}=0.05)$, 性差は $\chi^{2}=0.132<3.84(\mathrm{P}=0.05)$ となり，SPG 投与群，非投与群間汇有意盖を認めなかった。 な赫，（）内の数僬は街後UFT が投与されたるのを示す。

表 2 a SPG 投与群の原発部位・病期分類

\begin{tabular}{|c|c|c|c|c|c|}
\hline & Stage I & Stage II & Stage $\mathbb{I I}$ & Stage IV & 計 $(\%)$ \\
\hline 幽肉 & $2(1)$ & 2 & 7 & $3(2)$ & $14(46.7)$ \\
\hline 舌 & $4(1)$ & 2 & $3(2)$ & & $9(30.0)$ \\
\hline 口底 & 1 & $3(1)$ & 1 & & $5(16.7)$ \\
\hline 上顎洞 & & & $1(1)$ & 1 & $2(6.7)$ \\
\hline$\left(\begin{array}{l}\text { 計 } \\
\%\end{array}\right)$ & $\begin{array}{l}7(2) \\
23.3\end{array}$ & $\begin{array}{c}7(1) \\
23.3\end{array}$ & $\begin{array}{l}12(3) \\
40.0\end{array}$ & $\begin{array}{c}4(2) \\
13.3\end{array}$ & $30(8)$ \\
\hline
\end{tabular}

表 $2 \mathbf{b}$ 非投与群の原発部位・病期分類

\begin{tabular}{l|c|c|c|c|c}
\hline & Stage I & Stage II & Stage II & Stage IV & 計 (\%) \\
\hline 䔐肉 & $1(1)$ & $4(2)$ & 1 & $3(1)$ & $9(29.0)$ \\
舌 & $5(1)$ & 3 & 4 & 4 & $16(51.6)$ \\
口底 & & & 1 & 1 & $2(6.5)$ \\
上顎洞 & & & $3(1)$ & & $3(9.7)$ \\
煩粘膜 & & & 1 & & $1(3.2)$ \\
\hline 計 & $6(2)$ & $7(2)$ & $10(1)$ & $8(1)$ & $31(6)$ \\
$(\%)$ & 19.4 & 22.6 & 32.3 & 25.8 & \\
\hline
\end{tabular}

* $2 \times \mathrm{n}$ のカイ 2 乗テストによって部位別は $\chi^{2}=5.52<9.45 （ \mathrm{P}=$ $0.05)$, Stage 別は $\chi^{2}=1.58<7.81(\mathrm{P}=0.05)$ 走し, SPG 投 与群，非投与群間に有意差を認めなかった。な扣，（）内の数値 は街後UFTが投与さ机たものを示す。

歯学部附属病院第 1 口腔外科にて, 外科的手術を行った 頭頸部癌 (扁平上皮癌) 患者のちち, 根治的切除症例 61 例を検討の対象とした。これらの症例に対し, 初診時年 荟，性別，原発部位，TNM 分類, Stage 分類, 治療 法, 術後転移扣よび再発の有無, 経過観察期間などにつ いて分析を行った。 TNM 分類は口腔扁平上皮癌症例で は, UICC (1978年) の分類 ${ }^{5}$ に従い，上靧洞癌症例で
は，JJC 案（1977年）の分類 ${ }^{6)}$ に徒った。な抎，背景因 子に㧍计る SPG 投与群, 非投与対照群間の有意差検定 のために $2 \times \mathrm{n}$ 分割表におけるカイ 2 乗検定を行った。

SPG 投与群は30例で，乙の年齡分布は 36〜 79藏で, 平均年龄は 58.8 歳であり，性別では男性18例，女性12例 であった（表 1 a ）. 非投与群は 31 例で，その年跲分布 は38～83歳で，平均年跲は58.6歳であり，性別では男性 
表 3 a SPG 投与群の原発部位別治療法

\begin{tabular}{l|c|c|c|c|c}
\hline & $\mathrm{R}+\mathrm{C}+\mathrm{S}$ & $\mathrm{R}+\mathrm{S}$ & $\mathrm{C}+\mathrm{S}$ & $\mathrm{S}$ & 計 \\
\hline 崡肉 & & $10(2)$ & 1 & $3(1)$ & $14(3)$ \\
舌 & & 2 & $2(1)$ & $5(2)$ & $9(3)$ \\
口底 & & & $3(1)$ & 2 & $5(1)$ \\
上腼洞 & $2(1)$ & & & & $2(1)$ \\
\hline \multicolumn{1}{c|}{ 計 } & $2(1)$ & $12(2)$ & $6(2)$ & $10(3)$ & $30(8)$ \\
\hline
\end{tabular}

表 $3 \mathbf{b}$ 非投与群の原発部位別治療法

\begin{tabular}{l|c|c|c|c|c}
\hline & $\mathrm{R}+\mathrm{C}+\mathrm{S}$ & $\mathrm{R}+\mathrm{S}$ & $\mathrm{C}+\mathrm{S}$ & $\mathrm{S}$ & 計 \\
\hline 速肉 & & $4(2)$ & $2(1)$ & $3(1)$ & $9(4)$ \\
舌 & & 5 & 2 & $9(1)$ & $16(1)$ \\
口底 & & 2 & & & 2 \\
上顎洞 & $3(1)$ & & & & $3(1)$ \\
頓粘膜 & 1 & & & & 1 \\
\hline \multicolumn{1}{c|}{ 計 } & $4(1)$ & $11(2)$ & $4(1)$ & $12(2)$ & $31(6)$ \\
\hline
\end{tabular}

$\mathrm{R}$ ：故射線療法， C：化学療法， S: 外科的療法

（）内の数值は街後UFT が投与されたものを示す。

生存㳯

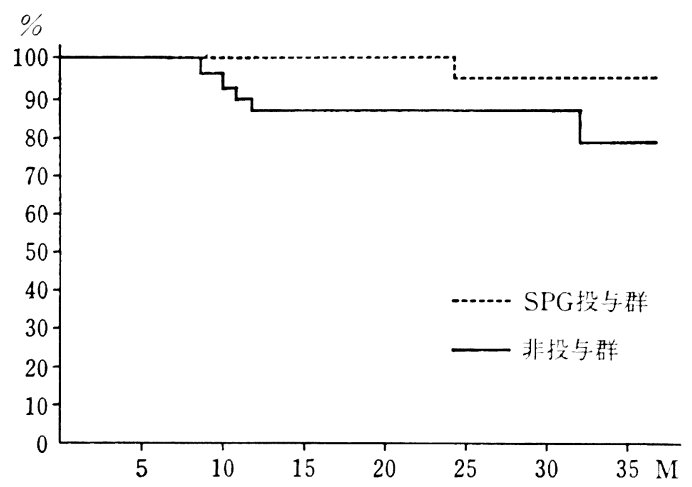

図 1 累程生存率 (Kaplan-Meicr 法)

SPG 投与郡 $(n=30)$, 非投与群 $(n=31)$

20例，女性 11 例であった（表 $1 \mathbf{b}$ ），有意差検定で， 性差で $\chi^{2}=0.132<3.84(\mathrm{P}=0.05)$, 年断分布で $\chi^{2}=$ $5.32<11.07(\mathrm{P}=0.05)$ となり，い与゙れも $\mathrm{SPG}$ 投与, 非投与雨群間に有意差を認めなかった。

$\mathrm{SPG}$ 投与群の部位別快，来肉14例，舌 9 例，口底 5 例, 上買洞 2 例, Stage分類で, I 期 7 例, II 期 7 例, III期12例， IV 期 4 例であった（表 $2 \mathbf{a}$ ）。非投与群の部 位別は，畨肉 9 例，舌16例，口底 2 例，上䫁洞 3 例，頓 粘膜 1 例で Stage 分類では I 期 6 例, II 期 7 例, III 期
SPG 投与群非投与群

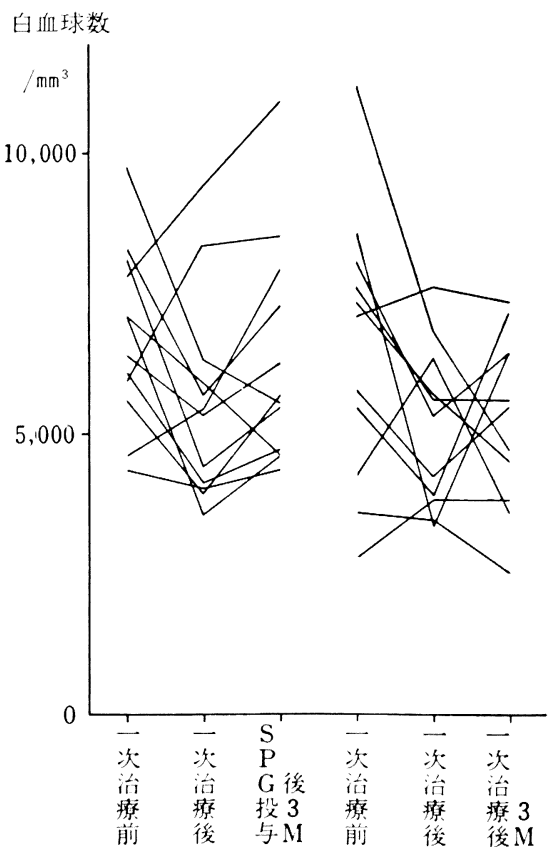

図 2 治港に伴 5 白血球の推移

統計学的（ $\mathrm{t}$ 检定）には両群問に有意差を認め なかった。 
表 4 a SPG 投与群の Stage 別治療法

\begin{tabular}{c|c|c|c|c|c}
\hline & $\mathrm{R}+\mathrm{C}+\mathrm{S}$ & $\mathrm{R}+\mathrm{S}$ & $\mathrm{C}+\mathrm{S}$ & $\mathrm{S}$ & 計 \\
\hline Stage I & & & 1 & $6(2)$ & $7(2)$ \\
Stage II & & 2 & $3(1)$ & 2 & $7(1)$ \\
Stage II & $1(1)$ & 7 & $2(1)$ & $2(1)$ & $12(3)$ \\
Stage IV & 1 & $3(2)$ & & & $4(2)$ \\
\hline 計 & $2(1)$ & $12(2)$ & $6(2)$ & $10(3)$ & $30(8)$ \\
\hline
\end{tabular}

表 4 b 非投与群の Stage 別治療法

\begin{tabular}{c|c|c|c|c|c}
\hline & $\mathrm{R}+\mathrm{C}+\mathrm{S}$ & $\mathrm{R}+\mathrm{S}$ & $\mathrm{C}+\mathrm{S}$ & $\mathrm{S}$ & 計 \\
\hline Stage I & & & $1(1)$ & $5(1)$ & $6(2)$ \\
Stage II & & $4(1)$ & & $3(1)$ & $7(2)$ \\
Stage II & $4(1)$ & 3 & 1 & 2 & $10(1)$ \\
Stage IV & & $4(1)$ & 2 & 2 & $8(1)$ \\
\hline 計 & $4(1)$ & $11(2)$ & $4(1)$ & $12(2)$ & $31(6)$ \\
\hline
\end{tabular}

$\mathrm{R}$ ：放射線療法， C：化学療法， S: 外科的療法

（）内の数值は術後UFT が投与されたものを示す。

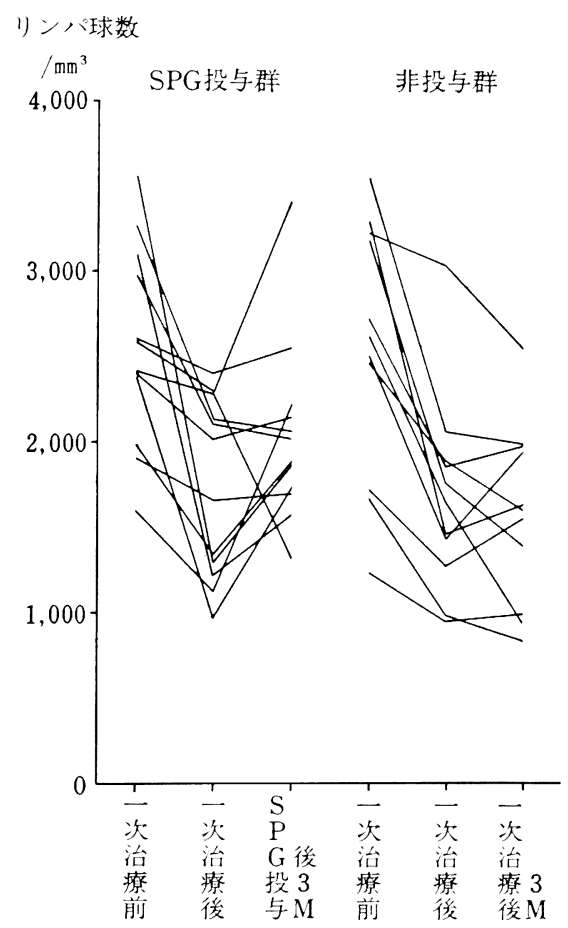

図3リンパ球数の推移

治療後 3 か月時のリンパ球数はSPG 投与群に 増加傾向が認められた $(\mathrm{P}<0.06)$.

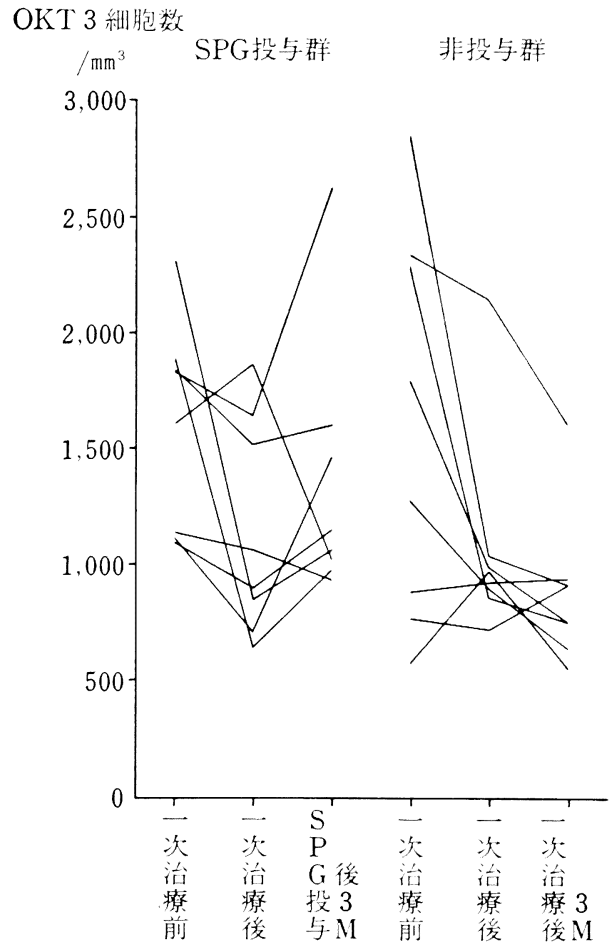

図 4 OKT3 陽性細胞数の推移 治嫄後 3 か月時の OKT3 細胞数は SPG 投与 群に增加傾向加認められた $(\mathrm{P}<0.08)$. 


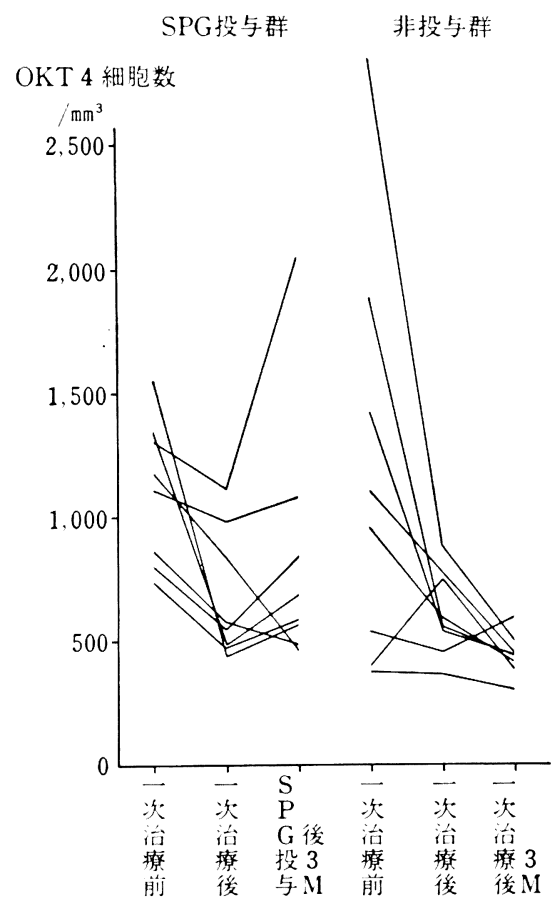

図 5 OKT4 陽性細胞数の推移

治療後 3 か月時 OKT4 細胞数: SPG 投与群 に增加傾向が認められた $(\mathrm{P}<0.06)$.

10 例, $\mathrm{N}$ 期 8 例であった（表 $2 \mathbf{b}$ ). 部位別では $\chi^{2}=$ $5.52<9.49(\mathrm{P}=0.05)$, Stage 分類では $\chi^{2}=1.58<7.81$ $(\mathrm{P}=0.05)$ となり, いずれも $\mathrm{SPG}$ 投与, 非投与雨群間 に有意差を認めなかった。

原発部位別治療法を表 $3 \mathbf{a} ， \mathbf{b}$ に示した。 3 者例用療 法が行われた上顎洞癌は, 投与群, 非投与群ともに, Co-60 による外部照射と $5 \mathrm{Fu}$ 動注の後, 上顎洞開洞あ るいは根治手術を行ったものである。非投与群の煩粘膜 癌の 1 例は, Co-60 による外部照射, シスプラチン, マ イトマイシンC, ペプロマイシンの静注後, 根治手術が 行われた。放射線・外科的療法璔用症例は, 投与群, 非 投与群ともにCO-60による外部照射の後, 手術を行っ たものである。化学・外科的療法を作用した症例では， Neo-adjuvant chemotherapy として, シスプラチン, ピンクリスチン, ペプロマイシンの静注を 2 クール行っ た後，手術が施行された。なお Stage 別治療法を表4 a , bに示した。

\section{投与 法}

SPG の投与は一次治療終了後, 1 か月以内に行われ
SPG 投与群非投与群

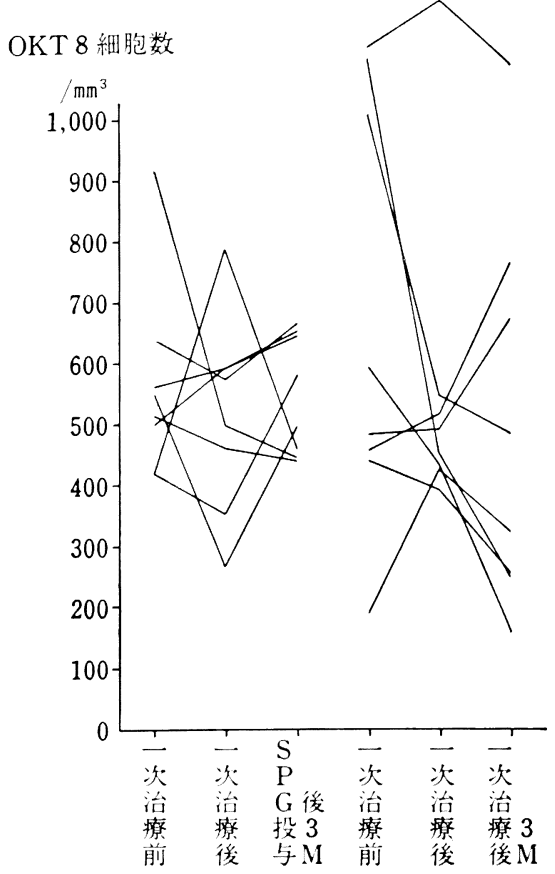

図 6 OKT8 陽性細胞数の推移

統計学的 ( $\mathrm{t}$ 検定) には両群間に有意差を認め なかった。

た. 投与は原則的に 2 週間ごとに $40 \mathrm{mg}$ が筋内内注射に て行われた，総投与量は280〜 $1,520 \mathrm{mg}$ で，平均投与量 は913.3土377.7 mg であった。

結

果

今回検討の対象とした61例の予後は，すべて追跡調査 が可能であった。㹩過観察期間は, SPG 投与群が 16〜 41 力月, 平均 27.8 力月, 非投与群が $8 \sim 53$ か月, 平均 34.5か月であった。投与群では1例が後転移により死亡 しており，非投与群では 6 例が死亡し，腫瘍死が 4 例， 心不全が 1 例，自殺が 1 例であった. Kaplan-Meier 法7)にて両群の累積 3 年生存率を比較すると, 投与群 が95. $2 \%$, 非投与群が78.4\%の結果が得られた（図 1). なお，両群の生存率のZ検定を行ったところ，32か月以 降に拈いて危険率 $5 \%$ 以下で統計学的に有意差が認めら れた。なお，30例の SPG 投与群中 8 例之非投与群31例 中 6 例にUFT 投与が行われていた。 そこで，その影響 をみるため UFT 投与 14 例と非投与 47 例との累積 3 年生 存率を調べると，投与群では69.6\%，非投与群で $87.1 \%$ であった。 


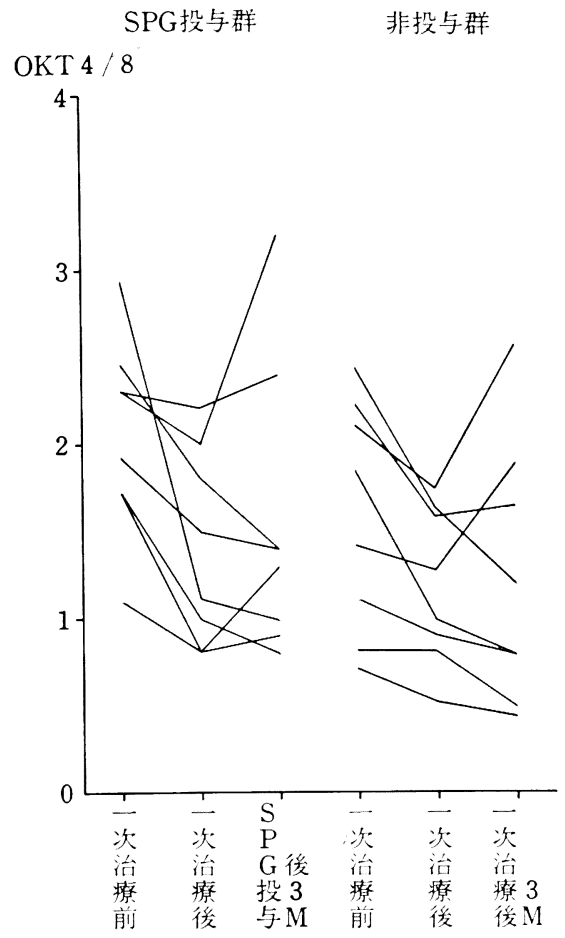

図 $7 \mathrm{OKT} 4 / 8$ 比

統計学的 ( $\mathrm{t}$ 検定) には両群間に有意差を認め なかった。

対象のらち, 放射線療法, 化学療法併用したものの なかから一次治療の前後を通じて，末梢血白血球数およ びリン・゙球数を経時的に測定した。白血球数は，放射 線・化学療法に上り減少を示した。一次治療後 3 力月目 に白血球数の変化をみると, 非投与群で11例中 4 例に上 界がみられたのに対し，SPG 投与群では，12 例中 9 例 に白血球数の上昇が認められた（図 2)。末梢血りンパ 球数も，放射楾・化学療法に上り 23 例全例が減少した。 治療後 3 か月目でリンパ球数を評価したところ, 非投与 群では，11例中 5 例のみに改善傾向が認められたのに対 し，投与群では12例中 9 例にリンパ球数の上昇傾向が認 められた（図了）。さらに，3か月目のリンハ球数の平 均值もSPG 投与群は, 非投与群に比較して高い值 (P ０.06）を示した。

さらに，放射線療法，化学療法を併用したもののなか から，一次治療の前後を通じて，リンバ球サブセット，

IL-2 産生能, IL-2 レセブタ一陽性細胞の変動を経時的 に測定した。 OKT3 および OKT4 陽性細胞は, リンパ 球数之同様に, 放射線・化学療法により減少した。非投 与群では両者の上昇傾向を認めなかったのに対して,

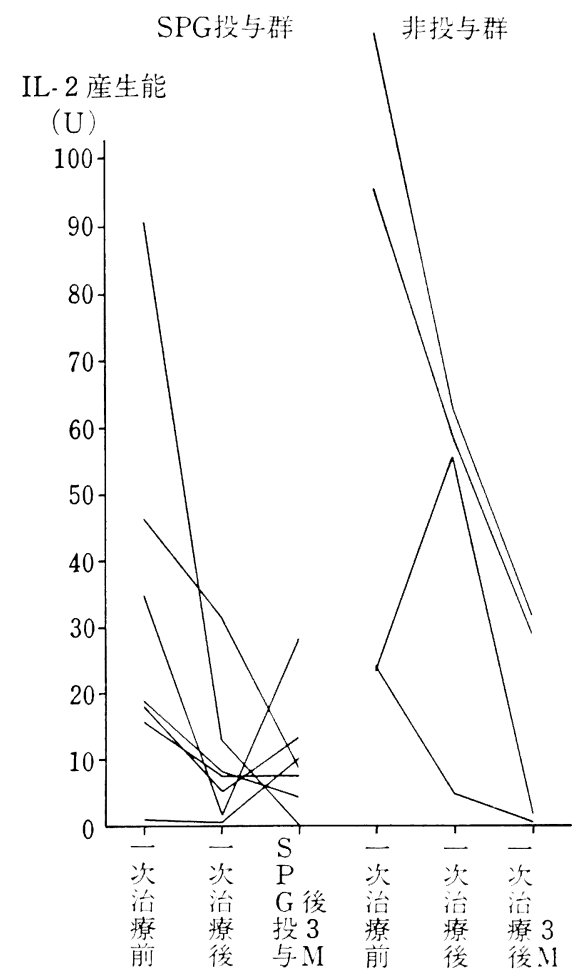

図 8 IL-2 産生能の推移

一次治療直後から治療後 3 か月までの変化婆は $\mathrm{SPG}$ 投与群 $(\mathrm{n}=7)$ て $7.57 \pm 10.7$, 非投与群 $(\mathrm{n}=4)$ で $0.37 \pm 0.19$ となった。

SPG 投与により OKT3 および OKT4 陽性細胞数は 增加傾向を示した $(\mathrm{OKT} 3, \mathrm{P}<0.08 ; \mathrm{OKT} 4, \mathrm{P}<$ 0.06)。一方, OKT8 陽性細胞は症例によるバラッキが 多く，両群間に有意の差が認められなかった（図 6). また OKT $4 / 8$ の変動についても，両群間に大きな差が 認められなかった（図 7 )。

IL-2 産生能については，症例によるバラッキが多く， 各治療時期の平均值で両群間に統計学的有意差をもと めることができなかった。しかし以下の傾向を示した。 すなわち, 放射線・化学療法によって IL-2 産生能は激 減し, SPG 投与によって西きらかに, そ机が回復する傾 向を示した。たとえば,一次治療直徯の值を1として, SPG 投与市るいは非投与 3 か月後の值をこの变化率之 して算定寸ると，SPG 投与群で $7.57 \pm 10.65$, 非投与群 で0.37土0.19で，SPG 投与群にあきらかな回復傾向が 認められた（図 8)、IL-2レセプター陽性細胞について も，症例によるバラッキが多かった（図９）。しかし， 治療後 3 力月時の平均值はSPG 投与群江高い值を示し た $(\mathrm{P}<0.05)$.

SPG の副作用としては, 注射局所の発赤, 硬結, 腫 
IL. 2 R 緗成技

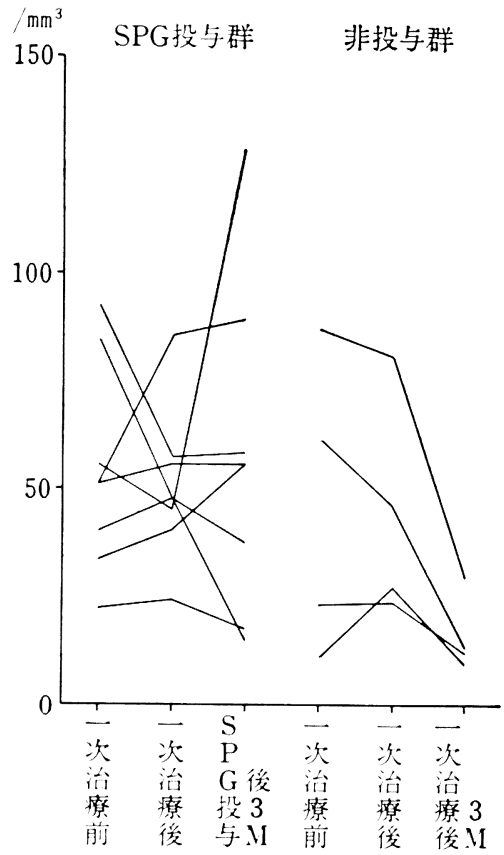

图 9 IL-2 レセプタ一陽性細胞数

治療後 3 か月時の IL-2レセプター陽性細胞数 法非投与群に比較して SPG 投与群に高值を示 した $(\mathrm{P}<0.05)$.

脹, 疼痛なとが数例認められたが，特に重篤なものはな かった。

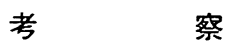

一次治療である外科的手術や放射線療法から逃れた微 小遗残病单を撲隇已せることは, 癌治療において大きな 意味をもつ.この目的のために, 術後の補助化学療法や 免疫療法が最近, 好九で行われるよらになった。しか し, 上記の補助療法がどの程度の効果をもつかについて 評価は現在のところ不明である。

当教室では，数年前より頭頸部癌術後の補助療法とし て SPG あるい: UFTを一部の患者に投与してきた。

UFT の評価については他施設との共同研究によって行 われているので, いずれ，その成績が報告されると思わ れる. 今回, SPG 投与群の延命効果や免疫パラメータ 一の糸化について分析した。

SPG は基礎動物実験で同種や同系の移植腫痬や自家 畽瘍に対して単独投与で抗腫瘍効果が認められてい $ろ^{1 \sim 3,8,9)}$. また, MMCゃ $5 \mathrm{Fu}$ との併用効果も報告さ

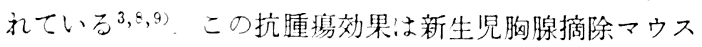
やヌードマウスでは著しく低下すること，また，マクロ
ファージの機能阻害剤投与によっても著しく低下するこ とから,この作用が宿主の免疫応答能を介したものと考 えられる。事夹, SPG 投与による各種エフェクタ一細 胞の誘導や活性の增強（細胞障害性 $\mathrm{T}$ 細胞の活性增強, マクロファージの細胞障害性の増強, NK $\mathrm{NAK}$ 活性 の増強）が基礎奏験によって認められている ${ }^{1 \sim 3)}$.

臨床的効果は子宮頸部癌において最も多く検討され, 特に放射線と併用において高い評価が示されている。最 近, 子宮頸部癌のみならず卵巣癌, 胃癌, 肺癌なとにお いてもその有用性が報告されている ${ }^{10 \sim 13)}$. 一方, 頭頸部 癌での評価は少ない14 18)

そこで今回, 頭頸部癌治癒切除症例61例について SPG 投与30例, 非投与31例の累積生存率について分析を行っ た。 その結果, SPG 投与群で $95.2 \%$, 非投与群で 78.4 $\%$ の 3 年累積生存率が示され, 両群のZ検定において, 統計学的に有意差を認めた。両群の背景因子をみると年 湛，性別では問題がないが，部位別では投与群で歯肉癌 が多いのに対して, 非投与群で舌癌症例が多くみられ た。特に通常予後不良である Stage Vの舌癌が非投与 群に 4 例も含まれており，その5ち2 例が腫瘍死してい る.しかしこの 2 症例を除外したとしてもあきらかに SPG 投与群に高い延命が認められた。ささらに背景因子 に亦计る SPG 投与, 非投与両群間に偏りが統計学的に 有意であるか否かについて $2 \times \mathrm{n}$ 分割表におけるカイ 2 乗テストを用いて検定すると, 性別, 年齡, 部位別, Stage 別のい寸゙れにおいても有意差を認めなかった。す なわち両群間の背景因子の分布が統計学的に差のないこ とが示された。なお，今回唡討した両群ともにUFTを 併用した症例が含まれていたので，UFT 投与，非投与 間の生存摔を比較したところ，むしろ非投与群の方が良 好な結果を示した。

放射線療法や化学療法が骨髄機能や免疫能を低下させ ることはよく知られている。.今回の研究でも，放射線や 化学療法によって白血球数, リンパ球数, $\mathrm{T}$ 細胞マーカ 一の OKT3, ヘルパー/インデューサーT細胞マーカー の OKT4 陽性細胞が著明に減少した。これらの症例に 対して SPG を投与すると, 減少したこれらの細胞数が すみやかに改善させることが示された。

細胞障害性/サプレッサーT細胞マーカーのOKT8に ついては，症例によるハララッキが大きく， SPG 投与群・ 非投与群間の著明な差異な評価することができなかっ t:.

IL-2 はへルパーT細胞に由来する㘿殖因子で細胞障 害性 $\mathrm{T}$ 緗胞, $\mathrm{NK}$ 細胞, $\mathrm{LAK}$ 細胞などの誘導や活性化 させる。これらの抗腫璋性をもつ免疫担当細胞の賦活を 期待して，IL-2 を直接生体に投与したり，in vitroにて 単核球をIL-2で処理することによって誘導された LAK 細胞を再移入する方法が臨床的にすで試みられてい る．今回の娭討では，治療前のデータをみてもわかるよ 
うに，IL-2 産生能は個体差のバラッキが大きいため， 治療前, 治療後の数値から得た平均值を両群間で比較し た場合，有意差を求めることができなかった。しかし， 個々の症例の $\mathrm{IL}-2$ 産生能の推移をみると, IL-2 産生 能は放射線や化学療法に上って著明に減少する結果が得 られた。減少した IL-2 産生能法非投与群ては增加傾向 を示さないのに対し，SPG 投与によりすみやかに上昇 する結果が得られた。なお，IL-2 レセプター陽性細胞

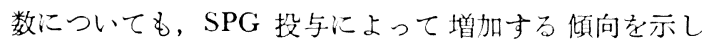
た。また，その他のサイトカイン IL-1， INFをもSPG が增強したり， NK 細胞をはじめとする各種

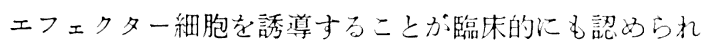
つつある。

以上述べたょうに，SPG :生物学的応答修飾物質 (Biological response modifiers, BRM) の1つとして宿 主免疫能の六進を介して抗腫瘍効果を示すと考克られ る. SPG は注射部位の炎症以外に重篤な副作用はなく, 術後の補助免疫療法古るい:放射線や化学療法之の併用 療法として有用であると思われた。

\section{結語}

口腔扁平上皮癌患者のう方, 治瘉切除症例61例中 30 例 に術後補助免疫療法の目的で, 多糖体製剂シゾフィラン (SPG) を投与した。 SPG の投与は 2 週間ごとに $40 \mathrm{mg}$ が筋肉内注射汇て行水机た。累積 3 年生存率は SPG 投 与群 30 例か $95.2 \%$, 非投与群 31 例が $78.4 \%$ で危除率 $5 \%$ 以下で統計学的に有意差が認められた。

さらに, ッンハ球数, OKT3, OKT4, サブセット,

IL-2 産生能などの免疫パラメータ一の検索に执いて, 放 射線, 化学療法に上り低下した細胞性免疫能か SPG 投 与に上り回復することが示㖫された。

以上のごとく，SPG は頭頸部扁平上皮癌の補助免度 療法郕として有用と考克られた。

\section{引用 文 献}

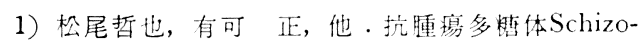
phyllan (SPG) の宿主免疫能促進作用。菜理 と 治療 9：1835-1843 1981.

2) 三谷满昭, 有可 正, 他：ラット同系嗹琹 A.IC - 60 線維肉腫拉よび BC-47 膀胱癌に対占 るSchizophyllan (SPG) の抗腫㾦效果。癌と 化学療法 11：1809-1817 1984 .
3) 岡 哲秀, 三輪怒沼, 他 : Schizophyllan(SPG) の $\mathrm{MH}-134$ 担癌 $\mathrm{C} 3 / \mathrm{He}$ マウス比对する抗腫

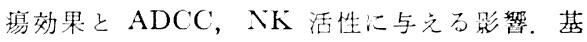
礎と臨朱 16：3989-3996 1982.

4) Okamura, K., Suzuki, M., et al.: Clinical evaluation of Schizophyllan combined with irradiation in patients with cervical cancer. Cancer 58: 865-872 1986.

5) UICC: TNM Classification of Malignant Tumors. International Union Against Cancer, Geneva, 1978.

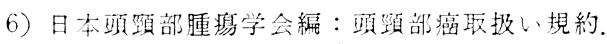
金原出勋, 東京, 1982，55-64面。

7) 富永祐民：治療初果判定のた的の央用統計学 蟹書房, 1985，76-122頁。

8）有可正，百木克夫，他：マウス同系腫場汇対 方子SPG の抗睡嫄効果. 基礎之臨床 15：247124811981.

9) 三谷满昭, 岩野滕行, 他 : Schizophyllanを用 いた癌化学免疫療法汇関なる基礎的研究。癌と 化学療法 9：122-128 1982.

10) 吉田弘一, 池内広重, 他: 街後消化器癌汇対与 万 SPG の Immunomodulator としての効果. 医学上薬学 5: 839-847 1981.

11) Fujimoto, S., Furue, H., et al.: Clinical evaluation of Schizophyllan adjuvant immunochemotherapy for patients with resectable gastric cancer. Jpn J Surg 14: 286-292 1984.

12) 吉田弘一, 折田萁三, 他: 胃癌得後補助療法㓮 としてのSPGの臨床評価(第 3 報)。BIOTHERAPY 1: 257-264 1987.

13）井出透，枝川濯一，他：人土七口夕ケ多蛅体 Schizophyllan (SPG) 単独古るいは併用による 進行痹治療の臨床的研究。癌と化学療法 8 : 1457-1463 1981.

14）梅津康生, 永山正明, 他: SPG, OK-432 牦用 免疫療法の癌患者木梢血単垓球構成江及活与影 響. BIOTHERAPY 1：86-91 1987.

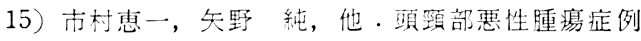
江对与る SPG の投与効果。耳鼠臨休 29：12161983.

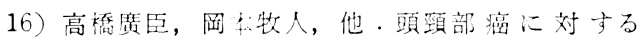
SPG 投与経駼。耳鼻臨東 25：436-442 1979 .

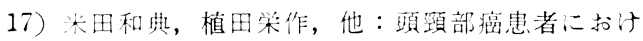
万Sizofiran (SPG) の免疫調節作用について。 BIOTHERAPY 4: 955-961 1990.

18）菊地白，安蒜昌去，他：口腔悪性嗹揘に对与

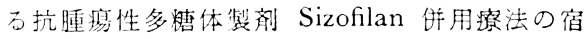
主免没賦活効果。品科誌 39：366-376 1990 。 